\title{
THE TEACHER EDUCATION OF SPECIALIST TEACHERS INCLUDING
}

\section{TEACHERS OF ENGLISH}

While most conferences, reports and articles concern themselves with the problems of the professional education of the normal classroom teacher at both primary and secondary levels, some of the published material makes reference to the professional preparation of specialist teachers, such as teachers of the English language, science, home economics, and technical subjects.

In part the needs of the Commonwealth countries for specialist teachers in those categories have been met by the Commonwealth Teacher Training Bursary Scheme. The Report of the Commonwealth Education Conference, 1959 (141) envisaged that the scheme would provide specialist professional education for college of education tutors ("the most valuable of all forms of help"), for the teachers of technical subjects in schools and for the teaching of English as a second language. This approach was elaborated at the Commonwealth Education Conference of 1962, when special attention was paid to the provision of assistance in the preparation of teachers of technical subjects in a scheme whereby teachers were to spend six months in a technical school in the United Kingdom, six months in industry and one year in a technical college of education. However, provision for this education is sometimes made locally; A.C. Pawson describes one example in his article 'Training Technical Teachers in Ghana' (71) in which he outlines the curriculum and methods of assessment of a course held in Kumasi; and, in the West Indies, the Report of Conference on Teacher Education 1967 (153) records a resolution that "the University of the West Indies assume an active role in .... assisting the territories in providing facilities for training an increased number of competent teachers in technical education".

Not surprisingly, most widespread attention is paid to the preparation of teachers of English as a second language. The report of the Regional Seminar on the Training of English Language Teachers (130) in South East Asia covers the ground in considerable detail; it describes the existing courses in South East Asia and outlines what might be done to improve the quality of English teaching within the existing framework; Dr. Robert Jacobs suggests some newer approaches; and $\mathrm{Dr}$. Donald $\mathrm{P}$. Horst gives an account of a programmed course for the training of English language teachers based on "a set of programmed textbooks, but extensive use is made of audio tapes, and sound movie films". Language teaching in South East Asia is also the subject of Tai Chen Hwa's paper 'The Training of Language Teachers' (124), which sees as the essential components of the course Linguistic Studies, the Psychology of Language Learning, Methodology and Research. Due emphasis is also given to the importance of language teaching in Dr. H.M. Sharif's article 'A Proposed Program of In-Service Education for Teachers with Special Reference to Improving the Teaching of the Language Arts in the Primary Schools of Pakistan' (85); "any attempt to improve the quality of primary teachers in Pakistan today must focus attention upon the improved teaching of the language arts". For West Africa appropriate suggestions are made by D.C. Miller in two articles. First, in 'Training and Equipping the Primary School Teacher of English as a 
Second or Foreign Language' (62), Miller looks at the four essential requirements for a language teacher at this level - some measure of linguistic sophistication, a clear knowledge of what has to be taught, some ability to use oral techniques and a flexible oral command of the language. Next, in 'Problems, Aims and Means in Training Graduate Teachers of English as a Second Language' (63) Miller considers the problems of the English language teacher in a college of education ; and then the essentials in preparing both the teacher of Language and the teacher of Literature. Also against a West African background R.S. Brandt describes 'A FirstYear Intensive English Course for Training Colleges' (14) followed at Bornu Training College, Northern Nigeria; his concern is with improving the general level of competence of English amongst students upon admission to a professional course. Most general of all in approach, both geographically and in content, is the series of articles edited by G.E. Perren in Teachers of English as a Second Language: Their Training and Preparation (72)

Some attention is also given to the professional preparation of science teachers. $Z$. Subarsky in his article on 'The Kenya Science Project' (94) describes the development of a scheme supported by the Ford Foundation to provide adequate science courses at the secondary level and the conduct of three week in-service courses for teachers in East Africa at the Science Teachers Centre. In the Report of the 8th Annual Conference of the Afro-Anglo-American Program (134) there is an account of the current work of the Kenya Science Teachers which is more fully described in Ingvar Karlen's article - 'The Kenya Science Teachers College' (49). The Report of the University of East Africa Conference on The Role of the Institutes of Education in Curriculum Development (138) contains papers by G.P. Oluoch on 'Primary Science Development in Kenya' and Dr. G.D. Bishop on 'Winds of Change in Science Education', both of whom advocate the adoption of 'discovery methods'. Several institutes of education in fact report special attention being given to science teaching, but in the report, University of Zambia - School of Education, 1968, (151) there is reference to its Science Education Centre which is "particularly concerned with the appraisal and modification of new science and mathematics curricula for local conditions and with more effective methods of teaching science".

One branch of science is given special attention in'A New Programme in Home Science in a Developing Country: Some Educational Considerations' (31) by W. Flemmung and K. Rhodes. This article is descriptive of a scheme, jointly sponsored by Cornell University and the Ministry of Education in Ghana, for the professional education of Home Science teachers; it provides a detailed account of a four year course leading to the award of an 'Institute of Education Diploma for Teachers of Home Science'.

And at a very practical level J.B. Blossom's article entitled 'Bricks With Very Little Straw' (11) centres upon the experiences of an art specialist in a college of education in Nigeria, the activities and methods he followed and the very real problems he faced. 